\title{
Managing the Effects of Tax Expenditures on National Budgets ${ }^{1}$
}

\author{
Zhicheng Li Swift
}

\begin{abstract}
:
Tax expenditures, in the form of tax provisions, are government expenditures. They are conceptually and functionally distinct from those tax provisions whose purpose is to raise revenue. Tax expenditure programs are comparable to entitlement programs. Therefore, tax expenditures must be analyzed in spending terms and integrated into the budgetary process to ensure fiscal accountability. In addition, tax expenditures must be audited for performance and the information must be published (with comprehensive analysis) to ensure fiscal transparency.

This paper analyzes the concept/definition, size, effects of tax expenditures, as well as the fiscal accountability and transparency of tax expenditure spending. In short, tax expenditures affect (1) the budget balance, (2) budget prioritization in allocation, (3) the effectiveness and efficiency of fiscal resources, and (4) the scope for abuse by taxpayers, government officials and legislators. While reviewing the current practices in tax expenditures against the requirements of fiscal accountability and transparency, the paper finds that this fiscal area must be strengthened.

The paper sketches four building blocks to strengthen tax expenditures towards fiscal accountability and transparency, based on the literature developed by Professors Stanley S. Surry and Paul $\mathrm{R}$ McDaniel, the practices from developed and developing countries, the Campos/Pradhan fiscal accountability model and the IMF's fiscal transparency code.

The paper argues that normative/benchmark tax structure, a revenue-raising component of the tax system, should be formalized. The normative/benchmark tax structure should be legally defined in the tax law and should be transparent. The tax receipts from this normative/benchmark tax structure should be quantified and published. Presently, many countries could publish imputed tax revenue from normative/benchmark tax structures, because such data is available. Only if imputed tax revenue is published in the same way as the other budget components -- tax revenue received, tax expenditures, direct expenditures and fiscal balance -- will a budget system be truly transparent in terms of revenue-raising activities and expenditure activities. In addition, when the tax revenue-raising activity is formalized, the inherent spending nature of tax expenditures is further exposed. Therefore, tax expenditures should be added to direct expenditures, forming total government expenditures. Furthermore, the conventional concept of the size of government should be remedied by including both direct expenditures and tax expenditures.
\end{abstract}

\section{World Bank Policy Research Working Paper 3927, May 2006}

The Policy Research Working Paper Series disseminates the findings of work in progress to encourage the exchange of ideas about development issues. An objective of the series is to get the findings out quickly, even if the presentations are less than fully polished. The papers carry the names of the authors and should be cited accordingly. The findings, interpretations, and conclusions expressed in this paper are entirely those of the authors. They do not necessarily represent the view of the World Bank, its Executive Directors, or the countries they represent. Policy Research Working Papers are available online at http://econ.worldbank.org.

\footnotetext{
${ }^{1}$ Zeljko Bogetic made important contributions to the paper through several discussions with the author. The author also thanks Anand Rajaram, Hana Polackova Brixi, Tuan Minh Le, and Christian Valenduc for contributions, comments and suggestions on earlier drafts.
} 
"Even though spending programs show up in the federal budget and tax expenditures are not included as federal spending, taxpayers are paying for the program in either case. Both should be transparent and subject to periodic oversight concerning such factors as whether they meet the program's objectives or conflict with other government programs, grants, and regulations that have similar objectives."

"Understanding the Tax Reform Debate: Background, Criteria, \& Questions" Government Accountability Office, The United States, September, 2005

Tax incentives are popular policy measures used in both high- and low- income countries, but there are differences in how high-income and low-income countries deal with them. The high-income countries (most of them Organization for Economic Cooperations and Development (OECD) member states) recognize that a tax incentive is a type of government spending in the form of a tax expenditure. A tax expenditure, a component of the tax system, functionally provides government financial assistance by not collecting tax revenue otherwise due. High-income countries have introduced tax expenditure accounting and subject tax expenditures to normal budgetary controls.

Many low-income countries, even those with high public debt and those in which the majority of the population is below the poverty line (less than US\$1 a day), have embraced tax incentives. Their spending in tax expenditures has decreased their revenue received, reducing these countries' capacity to assist the needs of the poor. Ironically, the poor do not benefit from tax incentives because their income is usually below the tax thresholds. None of these countries, so far, use tax expenditure accounting or subject tax expenditures to normal budgetary control. Many other transition economies and developing nations also use tax incentives, but in most cases they have not taken sufficient steps to make tax incentives accountable.

Similar to the differences between high- and low- income countries on tax incentives, there are differences of opinion between tax policy advisers. One group of tax policy advisers recognizes the concept of tax expenditures and understands that tax incentives are tax expenditures. They analyze tax incentives as spending items, using spending terminology. Other tax policy advisers attempt to discuss tax incentives as normative tax provisions. Stanley Surrey's comment on this approach: “A tax expenditure is a spending program and must therefore be analyzed in spending terms. To attempt to discuss the program as if it were a normative tax provision is to disregard this fact.” (Surrey and McDaniel, 1985).

This paper analyzes the concept/definition, the size and the effects of tax expenditures, as well as the fiscal accountability and transparency of tax expenditure spending, based on the literature developed by Stanley S. Surrey and Paul R. McDaniel, the experience and practice of the OECD countries (who have dealt with tax expenditures for about 30 years); the Campos/Pradhan fiscal accountability model and the IMF fiscal transparency code. This paper will focus primarily on those developing countries that are 
keen to apply the concept of tax expenditures but lack knowledge and experience ${ }^{2}$, Section I presents the concept of tax expenditures. Section II discusses the size and the fiscal effects of tax expenditures. Section III discusses fiscal accountability and transparency in tax expenditures. Section IV set forth the building blocks for fiscal accountability and transparency in tax expenditures. Section V concludes.

\section{A. Definition}

\section{The Concept of Tax Expenditures}

A tax expenditure, in broad terms, is a tax provision that deviates from a normative or a benchmark tax system. Tax expenditures may take a number of forms: exclusions, exemptions, allowance, deductions, credits, preferential tax rates, or tax deferrals. Tax holidays and tax free zones are tax expenditures subject to specific time periods or geographical areas.

To identify tax expenditures, a normative or a benchmark tax structure must be established. The normative or benchmark tax structure does not contain any tax provisions used to implement government spending programs for favored activities and groups.

"The tax expenditures concept recognizes that a tax system contains two components which are conceptually and functionally distinct, though interwoven, in the tax law. One component contains those provisions necessary to implement the normative tax structure; the other contains those provisions -- the tax expenditure provisions -whose function and effect are to implement government spending programs” (McDaniel and Surrey, 1985).

\section{B. Normative Income Tax Structure}

The concept of a normative, or benchmark, income tax structure was first introduced in the US in the 1960s. Its analysis is appropriate to any broad-based tax intended for general application, such as a consumption tax (for examples, a retail sales tax, or a VAT), a property tax, or a wealth transfer tax (Surrey and McDaniel, 1985) ${ }^{3}$.

In a normative income tax structure, the concept of "net income" is defined based on the Schanz-Haig-Simons (S-H-S) economic definition of income as an increase in net economic wealth between two points of time, plus consumption during that period. "Consumption" covers all consumption except that incurred as a cost in the earning or production of income. However, that income concept using the S-H-S approach covers a very wide range of income. In fact, some of the items within the definition of "net income" are not commonly regarded as income for tax purposes, though they fall within this economic definition of income. The S-H-S approach has to be moderated.

\footnotetext{
${ }^{2}$ For an example, China held a conference, “International Forum for Tax Expenditures,” in December, 2002 and invited experts from Australia, Belgium, Canada, the Netherlands, the World Bank, and the IMF to discuss the concept and practice of tax expenditure management around the world.

${ }^{3}$ For example, Canada also applies tax expenditure concepts to its goods and services tax. France applies tax expenditure concepts to its VAT.
} 
Also, the S-H-S approach does not specify the accounting technique to be used. A practical, commonly-used accounting technique, such as business accounting, must be identified. There are also other elements of a tax structure, such as the taxable unit, rate schedule, accounting period, and the determination of whether the tax base will be inflation-adjusted. There are no normative concepts for these elements. They reflect the decisions that must be made in accordance with fiscal and other policies. Once these decisions are made, any special departures from those decisions constitute tax expenditures.

To summarize, the concept of a normative income tax structure has been established in the US by the application of the S-H-S income concept, business accounting techniques, and the generally-accepted rules on with some exclusions of income (for example, the exclusion of "income" from unrealized appreciation in asset values) (Surrey and McDaniel, 1985). Because many elements of tax structures are decided based on "the generally-accepted rules," the normative income tax structure is also called the benchmark income tax structure.

Countries' tax laws differ in various aspects; so do definitions of normative or benchmark tax structures. As a result, applications of the definitions of tax expenditures (departures from normative tax structures) also differ from country to country (Box 1).

For example, a country may consider child-care expenses a cost of earning income and therefore a part of the benchmark tax structure, while others would consider tax assistance for child-care expenses to be a tax expenditure. 


\section{Box 1. Definitions of Tax Expenditures, Country Examples}

Austria: "Government income forgone due to exceptions from the general tax norm to the advantage of other agents with a view to their private activities performed in the interest of the general public."

Canada, using a broad approach: "only the most fundamental structural elements of each tax system are considered part of the benchmark." So that the deviations from tax benchmarks are tax expenditures

France: “Any legislative or administrative measure may be called a tax expenditures if its application entails a loss of revenue from the State, and hence a lessening of taxpayers' burden in comparison to that which would have resulted under the "norm", that is the general principles of French tax law.”

Germany: tax expenditures are those tax incentives that are special deviations from the central concept of a tax norm, which involve a shortfall of receipts.

Spain: "departures from the normal tax structure which represent tax incentives or tax subsidies”.

United States Federal Government: Tax expenditures are revenue losses resulting from federal tax provisions that grant special tax relief designed to encourage certain kind of behavior by taxpayers or to aid taxpayer in special circumstances. These provisions may, in effect, be viewed as spending programs channeled through the tax system (2000).

Sources: H. P. Brixi, et. al. 2003; K.C. Messere, 1993; and the US Congressional Research Service. 2002.

\section{Tax Expenditures and Related Transactions}

In the tax expenditure concept, two transactions are involved in tax revenue and in direct expenditures: the normative tax liability paid by taxpayers (calculated based on the normative tax structure -- tax expenditures excluded) and a government appropriation of funds to taxpayers who benefit from tax expenditure programs. However, governments use tax expenditures to short-circuit the direct spending process by having only one net payment (netting out the tax expenditures from normative tax liabilities) by the taxpayers (Surrey and McDaniel, 1985).

\section{Factors in the Revenue Process}

The tax expenditure concept recognizes that there are three key factors involved in the revenue process: the imputed normative tax revenue from a normative tax structure; tax expenditures; and "net tax revenue" or "tax revenue received." The relationship among those three factors can be stated as follows: "net tax revenue/tax revenue received" is the difference between the "normative tax revenue" and "tax expenditures." This relationship can be formulated as follows:

$$
\begin{gathered}
\text { Normative Tax Revenue }- \text { Tax expenditures }=\text { Net Tax Revenue (Tax Revenue } \\
\text { received) }
\end{gathered}
$$

\section{E. Tax expenditures vs. Entitlement Programs}

Tax expenditures are comparable to entitlement programs, which are direct expenditures. A tax expenditure allows any qualified taxpayer to reduce his or her tax 
liabilities, while an entitlement program is paid to all eligible persons. But there are fundamental differences in the appropriation of funds to tax expenditures and to entitlement programs. Tax expenditures are generally enacted as permanent legislation. Entitlement programs must be appropriated periodically through the budgetary process. There are many critics who argue that tax expenditures, like entitlement programs, should periodically be thoroughly reconsidered to determine whether they are efficiently meeting the needs and goals for which they were originally established (the US Congressional Research Service, 2002).

\section{Box 2. Tax Expenditure, Incentive, and Tax Penalty}

Tax expenditures vs incentives. All tax incentives are tax expenditures; they are designed to change behavior to achieve particular economic and social targets. But not all tax expenditures are tax incentives. Tax expenditures could be used to subsidize particular taxpayers. For example, tax subsides that are used to reduce hardships are tax expenditures, but they are not tax incentives.

Tax penalty. A tax expenditure is a deviation from a normative or a benchmark tax system. When a tax provision allows the government to collect more revenue than it would under the normative tax, this provision is equivalent to a directly imposed governmental fine or penalty. Such a provision is called a "tax penalty."

An example, in the personal income tax, would be the denial of a deduction for an expenditure that constitutes a cost of producing income, even though this expenditure would be deductible under normative principles. This denial does not relate to any incentive.

Therefore, in terms of tax expenditures, a tax penalty is the opposite of a tax expenditure, which increases revenue. Therefore, if we represent tax expenditures as positive figures (consistently with the treatment of direct expenditures), then tax penalties should be negative figures.

Source: McDaniel, P.R. and S. Surrey, "International Aspects of Tax Expenditures: A Comparative Study” 1985. 


\section{The Size of Tax Expenditures and Their Fiscal Effects}

\section{A. The Size of Tax Expenditures}

According to published country tax expenditure data, the size of tax expenditures varies among countries. In 2003, the size of tax expenditures was over 2 percent of GDP in the Netherlands, 4 percent of GDP in Australia, and about 7 percent of GDP, in Canada and in the US. Table 1 below gives the estimates of the average size of tax expenditures in Australia, Canada, the Netherlands, and the US from 2000 to 2003.

By comparing tax expenditures to integrated tax expenditures and direct expenditures (referred to as "total expenditures"), Table 1 shows that governments have used tax expenditures to implement a significant portion of their total expenditures. The Australian government has used tax expenditures to allocate 15 percent of its total expenditures; the Canadian government has used tax expenditures to allocate about 30 percent of its total expenditures; the Netherlands government has used tax expenditures to allocate 4 percent of total expenditures, and the US government has used tax expenditures to allocate 26 percent of its total expenditures. ${ }^{4}$

Like direct expenditures, tax expenditures tend to grow. Sometimes, the growth of tax expenditures is faster than that of direct expenditures. For example, according to recent released data from the Government Accountability Office (GAO) of the US, the federal government's tax expenditures increased from about US $\$ 400$ billion in fiscal year $1993^{5}$ to US $\$ 850$ billion in fiscal year $2004^{6}$ (which represents a 113 percent increase from 1993 to 2004). Federal direct expenditures were US\$1,409.5 billion in 1993 and US\$2,292.2 billion in 2004 (a 62 percent increase from 1993 to 2004). There are many similar examples from other countries.

Poland (central government only), for example, has not established tax benchmarks that could be used to compose a full list of tax expenditures, but the size of a number of commonly recognized tax incentives is large. According to a Ministry of Finance document ${ }^{7}$, over 300 tax incentives in the nature of tax expenditures have been established sine 1992. Among them, there were 200 tax incentives relating to personal income tax (PIT), and 100 tax incentives relating to corporate income tax (CIT) and VAT. According to the Polish Ministry of Finance, the estimated size of a group of 18 tax incentives in the PIT (less than 10 percent of the total of 200 PIT tax incentives) was 1 percent of GDP (annual average) from 1993 to 2000. If all the 300 tax incentives were estimated, the total cost would be significant.

\footnotetext{
${ }^{4}$ The aggregate total of tax expenditures has not taken into account changes in the behavior of taxpayers, nor the amount of tax reduction that may result when a taxpayer takes advantage of a tax expenditure; it may lower his/her tax bracket to a lower level in a progressive tax rate schedule.

5 “Tax Policy, Tax Expenditures Deserve More Scrutiny,” GAO, USA, June 1994.

6“Understanding the Tax Reform Debate,” GAO, USA, August, 2005.

${ }^{7}$ Poland Ministry of Finance, “The White Paper for Tax,” 1989.
} 
Table 1. Central Government Tax Expenditures, 1999/2000-2002/2003 (annual, in percent of GDP, unless otherwise specified)

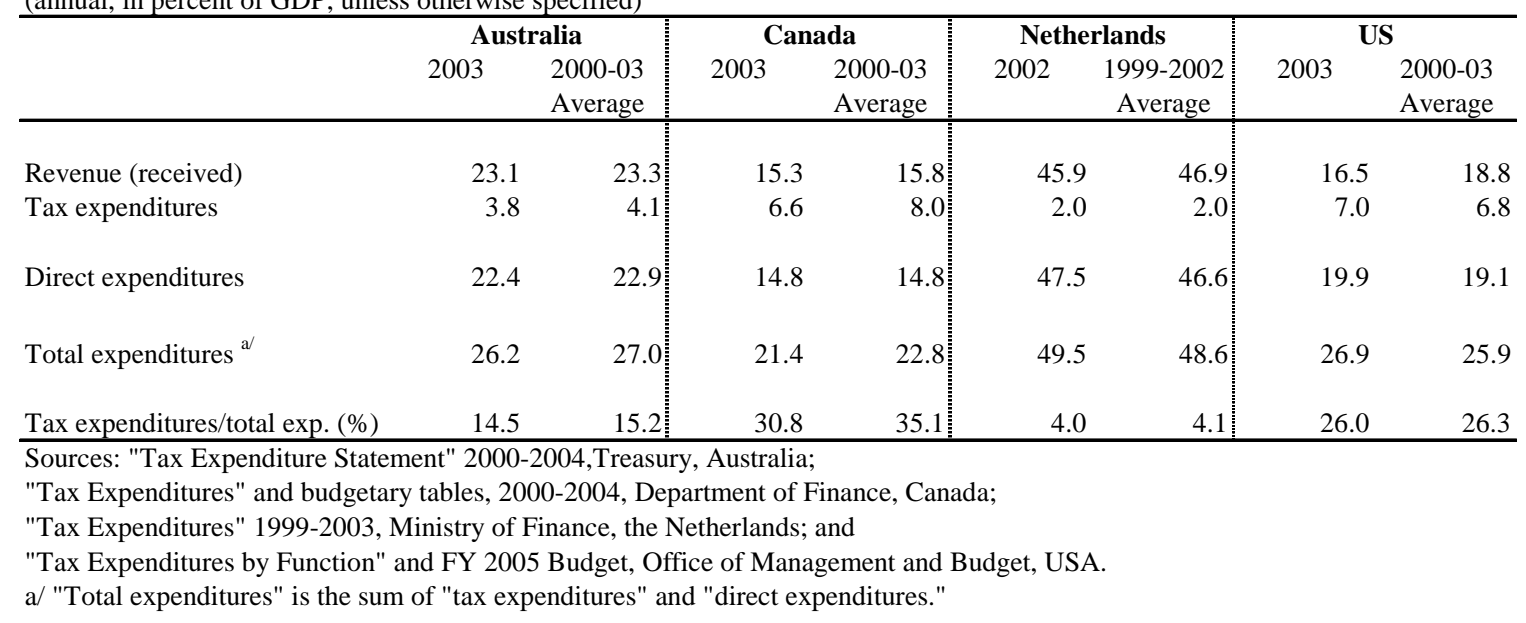

In Turkey (central government only) the potential tax benchmarks for PIT, CIT and VAT have been studied. A list of potential tax expenditures has been compiled that contains 186 tax expenditures relating to PIT, CIT, VAT, and special consumption tax. Most of these tax expenditures are on a large scale and are very generous. Recently, Turkey has officially estimated the cost of 15 tax expenditures provisions, which is $1.6 \%$ of GDP. However, according to various analyses and preliminary estimates from other organizations, the total cost of tax expenditures, adding the other omitted tax expenditures, would raise to at least 5\% of GDP in 2003.

In China (both central and local governments), for example, tax expenditure policy has become popular since 1978, when China launched an economic transformation from a planned to a social market economy. The government has not established a tax benchmark structure, but it recognizes that most tax incentives in its system are tax expenditures. The estimated cost of tax expenditures is not available to the public, even though the central government has made estimates for about 100 tax expenditures. However, according to a reputable tax expert in China, the total number of tax expenditures is probably 1000 , more or less ${ }^{8}$. The size of the tax expenditures could be well over $10 \%$ of $\mathrm{GDP}^{9}$ in 2002.

\section{B. The Effects of Tax Expenditures on the Budget}

Similarly to direct expenditures, tax expenditures, as spending items, affects fiscal budget balance, prioritizing resource allocation, efficiency and cost-effectiveness. Because tax expenditures (enacted as part of the tax law) constitute one component of a tax structure, the impact of tax expenditures on the simplicity of the tax administration is also discussed below.

\section{Tax expenditures reduce tax revenue, which affects the budget balance}

\footnotetext{
${ }^{8}$ Based on telephone interview with a Chinese expert in tax policy, conducted on October 19, 2005.

${ }^{9}$ H.P. Brixi et al., "Tax Expenditures -- Shedding Light On Government Spending Through the Tax System," 2004.
} 
Tax expenditures, in reducing tax revenue received (or net tax revenue), reduce the overall budget balance like direct expenditures. As a result, the overall budget deficit will increase or the overall budget surplus will decrease if direct expenditures are constant.

While reducing tax expenditures, net tax revenue will increase. As a result, the overall budget deficit will decrease or the overall budget surplus will increase if direct expenditures are constant.

Tax expenditures, directly financed from the tax base, are open-ended funding. Without periodically budgetary appropriation and review, tax expenditures are free to grow apace with changes in economy and society, which may increase spending. (For example, tax exemptions for income from social security in middle income countries increase when more people reach the age qualifying for those social benefits.) That openended spending aspect of tax expenditures, reducing net tax revenue, results in lack of control over the entire budget.

There are many examples from both developed and developing countries that widespread use of tax expenditures jeopardizes fiscal balance and fiscal sustainability. For example, the US Treasury listed 146 tax expenditures in 2004, which is up about 26 percent since the last major tax reform legislation in 1986. The total cost of tax expenditures is US\$850 billion (by outlay-equivalents measures) in 2004, which will lead to fiscal unsustainability. That situation was reported by the GAO in September 2005: “Absent policy changes on the spending and/or revenue sides of the budget, a growing imbalance between federal spending and tax revenues will mean escalating and ultimately unsustainable federal deficits and debt." For example, "if discretionary spending grows at the same rate as the economy and all expiring tax provisions are extended, federal revenues could be adequate to cover little more than interest on the federal debt by 2040.”

In another example, Bangladesh's tax system is plagued with numerous exemptions and tax holidays for both income tax and VAT. As a result, its net tax revenue, on average was 7.9 percent of GDP while its fiscal deficit on average was 3 percent of GDP from 1995 to 2004, and its total public debt was 51 percent of GDP by 2002. The large number of tax expenditures contributed to the low tax revenue received, as well as to the cause of fiscal deficit and high public debt ${ }^{10}$, leading to fiscal unsustainability.

10 “Bangladesh: Selected Issues,” IMF, June 2005. 


\section{Tax expenditures, because they are funded from the tax base, affect prioritizing fiscal allocations. Tax expenditures (regardless effective or efficiency) have a higher priority than direct expenditures (regardless of whether they are mandatory or discretionary).}

All tax expenditure programs automatically have a higher budget priority than direct expenditure programs, whether the direct expenditure programs are for national defense or social welfare programs. Even though the main concerns in many developing countries are economic growth and poverty reduction, tax expenditures have a higher priority than direct expenditure programs for infrastructure, economic growth, education, health, poverty reduction, and so forth. Most poor people do not benefit from tax expenditures because their incomes are below tax thresholds.

\section{Tax expenditures reduce the effectiveness and efficiency of public resource allocations: for example, some tax expenditures overlap or conflict with direct expenditures, some tax expenditures are outdated, and sometimes different tax expenditures are not coordinated.}

Tax expenditures have not been integrated into the budget process for appropriation. There is no requirement to coordinate them with respective budget allocations. As a result, some tax expenditures overlap, are redundant, or conflict with budget spending and objectives. Tax expenditures are usually do not have expiration dates or "sunset" provisions and are rarely reviewed. Some tax expenditures are not coordinated with other tax expenditures, undermining the effectiveness and efficiency in allocating public resources.

Tax expenditures are enacted as permanent changes in the tax structures. Some tax expenditures are outdated and are no longer effective because they were originally enacted in response to a particular set of economic and social conditions that have long since changed.

For example, in the United States, some tax expenditures overlap with direct expenditures. The tax credit provided by the federal government to assist in the construction of low-income rental housing overlaps with the grants provided by the Department of Housing and Urban Development (from the federal budget) to develop public for the same purpose. Also in the United States, a federal allocation program (a direct expenditure program) to clean up the lead, uranium and asbestos in the environment conflicts with an income tax credit (a tax expenditure) that subsidizes the production of these metals.

There are about 70 U. S. tax expenditures that were enacted before 1950. Based on the original objectives of those provisions, many appear no longer relevant. For example, the income tax exclusion of benefits and allowances to armed forces personnel was enacted in 1925. Its roots can be traced back to a temporary condition during World War I. The tax exclusion still exists even though this temporary condition seems no 
longer relevant. The revenue loss caused by this particular item is estimated to be US $\$ 2.9$ billion in 2005.

In Indonesia before the tax reform in 1984, there was a big revenue drain from the simultaneous operation of two uncoordinated tax expenditures. The Indonesian tax system exempted from interest income received on deposit accounts. However, the tax system allowed an unlimited deduction for interest paid on debt. Companies could easily arrange a borrow-and-redeposit scheme with their banks, yielding a deductible interest expense, and tax-free interest income. This was referred to as an "interest pump." The net effect was risk-free income at the expense of the treasury.

In China, there was a briefing from the Ministry of Finance about the overlap/redundancy, conflict, and noncoordination of tax expenditures that resulted in the waste of a large amount of public resources ${ }^{11}$.

\section{Tax expenditures increase the complexity of the tax system (second to structural provisions), and enormously complicate tax administration. Taking advantage of the complicated tax system and the overburdened tax administration, the abusive taxpayers would evade and avoid tax liabilities, causing more tax revenue loss.}

According to the tax expenditure concept, tax structures has two distinct components. The normative or benchmark tax structure functions by raising tax revenue (which contains structural provisions). The other component, tax expenditures, functions as government spending programs. Considering that the normative tax structure itself is extraordinary complex (for example, taxing the transactions across international borders and taxing the intricate financial transactions involving the capital structures of large corporations), tax expenditure provisions, in a second category, add increased unrelated complexity to the tax code. Nevertheless, if tax simplification is considered, tax simplification of structural provisions and of tax expenditure provisions involves distinct and generally not interchangeable criteria and objectives (Surrey and McDaniel, 1985).

Indeed, tax expenditure greatly complicate and overburden tax administration, especially when number and size of tax expenditures is large and hundreds of tax expenditure programs are carried out through tax system.

For example, The U.S. tax system is plagued with 146 tax expenditure programs at an amount of US\$850 billion, about 37 percent of direct expenditures. While direct expenditures are carried out by related special departments, tax expenditures are the responsibility of tax administration. Those tax expenditure programs encompass hundreds of specific programs with specific goals and conditions (for example, they are used for specific activities in national defense, environmental protection, historical preservation, energy, roads, education, and many other economic and social needs). All those

\footnotetext{
${ }^{11}$ Yaobin Shi, "Establishing a Tax Expenditure Administrative System That Achieves a Sound Fiscal System in China," in "Tax Expenditures-Shedding Light on Government Spending through the Tax System," 2004.
} 
programs require expertise that tax administration officials usually lack. Thus, the responsibility for carrying out tax expenditure programs adds complexity and causes ineffectiveness in tax administration.

Because the task for tax administration is enormous and complex, various schemes of tax abuse have emerged, such as transfer pricing, "company churning," "tailor-made loopholes," and so forth, which cause losses of revenue.

Tax holidays, for example, which provide tax incentives to business firms to invest in host countries or desired locations to promote economic growth, are often abused by using "transfer pricing." The firms transfer income from other subsidiaries and affiliated entities (including those in other countries) to the entity subject to tax holiday; then they divert/transfer expenses from that entity to taxable subsidiaries and affiliated entities.

Business also use "company churning” by liquidating and reconstituting existing companies to make them subject to the tax holiday provisions that apply only to new companies.

Business that are not qualified for tax holidays also try to tailor themselves to be subject to the tax holidays. For example, many multinational firms often use transfer pricing and "company churning” to avoid or evade their tax liabilities.

In China, there was a "tailor-made loophole" case in which a local Chinese company arranged to qualify for a tax holiday for foreign investments. That Chinese company transferred its funds to its bank account in Hong Kong. Then the company transferred its funds from its account with the Hong Kong Bank back to the mainland to become foreign investment (funding from Hong Kong was considered as foreign investment). Thus, this company received tax holidays that applied to foreign investment.

Abuse schemes can result in large tax revenue losses. Most of the business are large, have high incomes, and perform large transactions; by abusing tax expenditures, they caused heavy losses of tax revenue.

\section{Tax expenditures that are loosely subject to financial discipline/scrutiny provide an opportunity for abuse by government officials and legislators either for self- enrichment or to provide benefits to favored interests.}

Tax expenditures, a form of governmental financial assistance, have a direct and often large cash value to potential recipients. Consequently, companies and business groups have a strong motivation to lobby for tax incentives by exaggerating the prospective economic or social benefits. These lobbying activities often lead to a proliferation of tax expenditures and undermine spending efficiency and fiscal accountability. Also, the direct cash value of tax expenditures can become an open inducement to bribery and corruption. 
Abuses would be particularly likely when the discretion for granting tax expenditures is large, criteria are vague, agreements are confidential, and mechanisms are lacking to track and control revenue losses and other fiscal costs (Technical Report "Effectiveness and Economic Impact of Tax Incentives in the SADC ${ }^{12}$ Region," 2004). In Tanzania in 1996, the minister of finance authorized tax rate and tariffs rate reductions to four companies that imported 4,700 tons of cooking oil. As a result, both the minister of finance and the principal secretary in the president's office received US\$1.5 million from the four companies; the loss of tax revenue from the four companies amounted to US\$8.1 million. ${ }^{13}$

In India, a tax exemption was granted to the favorable partners of legislators. In the 1980s, an organization called Dardionu Rahat Fund (the fund) provided medicines, fruits and other requirements to poor patients free of cost. Minister of Finance Pranab Mukherjee and the Justice of Supreme Court P.N. Bhagwati attended a function organized by the fund. At function, which was not related to government spending issues, the Justice urged the finance minister to provide tax exemption to donations received by the fund, rather than through direct government aid, to increase the recognition of the fund ${ }^{14}$.

${ }^{12}$ SADC refers to "Southern Africa Development Community."

${ }^{13}$ Odd-Helge Fjeldstad, "Fighting Fiscal Corruption: The Case Of The Tanzania Revenue Authority," Chr. Michelsen Institute, Norway, 2002.

${ }^{14}$ The Times of India (Ahmedabad), September 8, 1982, p3. 


\section{Fiscal Accountability and Transparency}

Because tax expenditures are government spending (channeled through the tax system), they should be subject to the same fiscal accountability and transparency criteria as direct expenditures. This section reviews the practice and the extent of the challenges facing governments (of both developed and of developing countries) in applying the principles of fiscal accountability and transparency to tax expenditures.

\section{A. Fiscal accountability}

Under internationally accepted principles, fiscal accountability entails a state being held responsible by its people and by its elected bodies for its financial choices and for its actions in using public funds. Every government has an obligation to its people and to its elected bodies to provide a full and complete accounting of the way the government has discharged its responsibilities. According to Campos/Pradhan model (Campos and Pradhan, 1996), fiscal accountability consists of three goals or levels of expenditure management for which governments should be accountable:

- Level 1: overall control, within sustainable limits, involving medium-term expenditure frameworks (MTEF), financial discipline and compliance with laws and budgets.

- Level 2: strategic prioritization of resource allocation.

- Level 3: efficient and cost-effective management of programs.

To analyze fiscal accountability under the three levels above, data (on estimated and projected tax expenditures) are essential to enable governments to achieve the accountability criteria on tax expenditure spending. For that purpose, normative or benchmark tax structures and tax expenditures must be identified from the tax structures. Thus, tax expenditures can be estimated and projected.

However, both estimates and projections of tax expenditures, as well as tax benchmarks/norms, are not always available in some countries. These countries have different practices in establishing normative tax structures and estimating and projecting tax expenditures. In this paper, we divided countries into three groups according to country practice. In group 1, countries have identified both normative or benchmark tax structures and tax expenditures, and produced estimates and projections for all tax expenditures. In that group, most countries are high income OECD member states (including Australia, Austria, Belgium, Canada, Denmark, Finland, France, Germany, Greece, Ireland, Italy, Republic Korea, the Netherlands, Norway, Sweden, Switzerland, United Kingdom, United States ${ }^{15}$ ). In group 2, countries may or may not have identified normative/benchmark tax structures, nor tax expenditures, but they have produced partial estimates of tax expenditures (considered significant either financially or politically), with or without projections. In that group, most countries are transition economies or

\footnotetext{
15 This list may not be complete.
} 
developing countries. In group 3, countries have identified neither normative or benchmark tax structures nor tax expenditures. These countries have not estimated nor projected tax expenditures. In that group, countries are transition economies or developing countries.

Table 2 provides a brief overview of selected countries on the identification of normative or benchmark tax structures and of tax expenditures, as well as the status in estimating and projecting tax expenditures. Fiscal accountability can be described as follows:

In group 1 , for fiscal accountability at level 1 , these countries are able to control overall public expenditure and impose financial discipline on tax expenditures within sustainable level and MTEF. However, fiscal accountability at level 2 of strategic allocation of resources was not satisfied by all of those countries. When tax expenditures must be parallel to direct expenditures for appropriation to be prioritized, there are differences among the countries in integrating tax expenditures into the budget process to strategically prioritize resources (Table 3). For fiscal accountability at level 3 of the effectiveness and efficiency for individual tax expenditure, those countries have employed, more or less, an evaluation of cost-effectiveness, reviewing tax expenditures periodically, though some countries are proactive to deal with ineffectiveness tax expenditures than the others.

Countries in group 2 estimate partial tax expenditures because they recognize that tax expenditures cause revenue loss. However, because most of them have not established normative or benchmark tax structures, composing a full list of tax expenditures is difficult, as is estimating the overall size of tax expenditures.

For fiscal accountability in tax expenditures for those countries, at level 1, they may be able to control tax expenditures partially, but they can not control overall tax expenditures. At levels 2 and 3, obviously, the countries in group 2 have not complied with the criteria for achieving fiscal accountability.

Countries in group 3 have neither established normative tax structures, nor estimated/projected any tax expenditures. Those countries fail in compliance with fiscal accountability in tax expenditures. 
Table 2: Tax Expenditure Benchmarks And Availability Of Estimates And Projections (selected countries, data are preliminary)

\begin{tabular}{|c|c|c|}
\hline & Structural benchmarks & Data on tax expenditures \\
\hline Australia & A conceptual tax base (five benchmarks) & Estimated and projected \\
\hline Austria & A regulatory benchmarks & Estimated and projected \\
\hline Belgium & A national conceptual benchmarks & Estimated and projected \\
\hline Canada & Conceptual benchmarks & Estimated and projected \\
\hline Finland & Conceptual benchmarks & Estimated and projected \\
\hline France & Regulatory baselines & Estimated and projected \\
\hline Germany & $\begin{array}{l}\text { Tax expenditure is characterized as bring } \\
\text { analogous to an expenditure subsidy. }\end{array}$ & Estimated and projected \\
\hline Greece & Regulatory baselines & Estimated and projected \\
\hline Ireland & National conceptual baseline & Estimated and projected \\
\hline Korea, Republic & Regulatory baselines & Estimated and projected \\
\hline Netherlands & Regulatory baselines & Estimated and projected \\
\hline Portugal & Regulatory baselines & Estimated and projected \\
\hline Spain & Conceptual benchmarks & Estimated and projected \\
\hline Sweden & Conceptual benchmarks & Estimated and projected \\
\hline United Kingdom & Similar to the method used in Germany & Estimated and projected \\
\hline United States & $\begin{array}{l}\text { Conceptual baselines and regulatory } \\
\text { baselines }\end{array}$ & Estimated and projected \\
\hline Argentina & -- & Partial estimates \\
\hline Bangladesh & No. & Partial estimates \\
\hline Brazil & Regulatory benchmarks & -- \\
\hline Bulgaria & -- & Partial estimates \\
\hline China & No. & Partial estimates \\
\hline Latvia & No. & Partial estimates \\
\hline Hungary & -- & Partial estimates \\
\hline India & No. & Partial estimates \\
\hline Poland & No. & Partial estimates \\
\hline
\end{tabular}

Notes: "--" information is not available.

Sources: Jon Graig and William Allan, " Fiscal Transparency, Tax Expenditures and Budget

Processes: An International Perspective," Working Paper, IMF, 2001.

William Allan and Taryn Parry, "Fiscal Transparency in EU Accession Countries: Progress and Future Challenges," Working Paper, the IMF, 2003.

Carlos Cavalcanti and Zhicheng Li, "Reforming Tax Expenditures Program in Poland," Policy Research Working Paper, the World Bank, 2001. 
Table 3. Tax Expenditures Integrated into Budget Process (Selected countries, preliminary data)

\begin{tabular}{l|l}
\hline Australia & A separate government document. \\
\hline Austria & As an annex, part of "Subsidy Report" to budget documents \\
\hline Belgium & An annex to budget \\
\hline Canada & Not linked to budget process, but for pre-budget consultation. \\
\hline France & Appended to budget bill. \\
\hline Germany & As a part of budget, called "Subsidy Report" \\
\hline Italy & $\begin{array}{l}\text { Not linked to budget process, nor as annex to budget document. } \\
\text { but an independent document. }\end{array}$ \\
\hline Netherlands & $\begin{array}{l}\text { As an annex to the budget memorandum, not directly linked to the } \\
\text { budget but severs as an additional background information for the } \\
\text { Parliament }\end{array}$ \\
\hline $\begin{array}{l}\text { United } \\
\text { Kingdom }\end{array}$ & $\begin{array}{l}\text { Not linked to budget process, nor as annex to budget document, } \\
\text { but as part of statistical supplement to Autumn Statement (revenue) }\end{array}$ \\
\hline United States & $\begin{array}{l}\text { As part of annual budget documents, but is not integrated into the } \\
\text { budget process }\end{array}$ \\
\hline
\end{tabular}

Source: H.P. Brixi et al,. "Tax Expenditures-Shedding Light On Government

Spending Through The Tax System," the World Bank, 2003.

\section{B. Fiscal transparency}

Transparency in government operations has several dimensions. First, at the aggregate level, transparency requires the provision of reliable information on the government's fiscal policy intentions and forecast. Second, detailed data and information are required on government operations, including the publication of comprehensive budget documents that contain properly classified accounts for the general government and estimates of quasi-fiscal activities conducted outside the government. Third, behavioral aspects must be present, including clearly established conflict-of-interest rules for elected and appointed officials, freedom-of-information requirements, a transparent regulatory framework, open public procurement and employment practices, a code of conduct for tax officials and published performance audits (Shende and Bennet, 2004). These aspects and dimensions of transparency are consistent with the IMF's principles of fiscal transparency.

The IMF has set out four principles that define transparency that should be expected of a government:

- Clarity on the structure and functions of government, responsibilities within government and relations between government and the rest of the economy;

- Public availability of comprehensive information on public sector financial stocks and flows, published at specified times; 
- Public availability of information on how budgets are prepared and executed and minimum content of budgets and financial reports; and

- Financial data meeting accepted quality standards and subjected to independent audit scrutiny (IMF, “Manual on Fiscal Transparency, 2001).

For tax expenditure, countries comply with fiscal transparency differently among group 1 (established tax benchmarks and estimated and projected tax expenditures), group 2 (no established tax benchmarks, but partially estimated tax expenditures), and group 3 (no established tax benchmarks, no estimated tax expenditures). The situation can be illustrated as follows:

In group 1, all countries publish tax expenditure estimates and projections by types of taxes and by functional classification in the central government. Some countries also publish limited local governmental tax expenditures.

However, none of the countries has published imputed tax revenue from a normative tax structure to make comprehensive information publicly available even though that information is available during the process of estimating tax expenditures and is critical background for tax expenditures and the transparency of the size and magnitude of tax expenditures. Also, none of the countries has performed audits or published related auditing information. This group is not completely satisfied with the fiscal transparency criteria in tax expenditures.

For example, both the U.S. Treasury and the Congressional Joint Committee estimate and project tax expenditures. Both of them publish such information regularly. The GAO also publishes reviews and analyses of the effectiveness and efficiency of tax expenditures spending, their impacts on fiscal finance and the economy, and recommendations to improve them. However, neither Treasury nor the GAO publishes the imputed normative tax revenue.

In Germany the "Subsidies Report” includes both budgetary direct subsidies and tax provisions with estimates and projections. This publication is useful to assess the efficiency of total government financial assistance and to reduce overlap and conflict spending between tax expenditures and subsidies. Recently, Germany has studied and intends to audit tax subsidies. However, the imputed normative tax revenue is not published in any government documents.

In group 2, though some countries estimate partial tax expenditures and produce limited projections, they do not publish those estimates and projections. They do not compose a complete list of tax expenditures, either. Those estimates and some projections are not available to the public, but are only used for internal purposes by governmental agencies. Therefore, those countries have failed in fiscal transparency in tax expenditures.

In group 3 countries do not estimate tax expenditures or publish lists of tax expenditures. Tax expenditures are a black box to the public. Therefore, they fail in fiscal transparency in tax expenditures. 


\section{Building Blocks for Fiscal Accountability and Transparency}

This section discusses the building blocks to ensure spending on tax expenditures is accountable and transparent. There are four essential building blocks: (1) distinguishing the two components in the tax structure: the normative or benchmark tax structures and tax expenditures; (2) estimating and projecting tax expenditures; (3) integrating tax expenditures into budget and budget process for ensuring fiscal accountability; (4) auditing tax expenditures and publish comprehensive information to the public to ensure fiscal transparency.

The building blocks are based on internationally recognized literature on tax expenditures, fiscal accountability, transparency, and experience in developed and developing countries. Though the building blocks are mostly applicable to developing countries, they are also useful to developed countries to improve fiscal accountability and transparency in tax expenditures.

\section{Building block 1. Distinguishing the normative/benchmark tax structure and tax expenditures}

According to practices in developed countries, the distinguishing the two components in the tax structure can be performed in parallel. The identification of the component of a normative tax structure can be preceded by responding to one of the questions (6 of them) in the Box 3 below.

Behind each of the 6 questions is a pure tax policy decision on tax base, rate structure, taxable unit, tax period, international transactions, and tax administration; so the given provision can be identified either as a normative tax structures or a tax expenditures. Seven developed countries (Canada, Germany, France, the Netherlands, Sweden, United Kingdom and United States) have used that guideline to identify their normative tax structures and tax expenditures.

Normative tax structures among developed countries, however, differ because of the policy choices in tax rate, tax structures, taxable unit, tax period, international transactions and tax administration because of differences in national politics, history, philosophy, sociological, and the like. Despite those differences, most tax structures employed in the world include provisions that are not responsive to one of the questions posed in Box 3. Therefore, they do not form part of the normative tax structures; they are tax expenditures. The questions in Box 3 were formulated by McDeniel and Surry for developed countries.

For transition and developing economies, the guideline in Box 3 is essential to distinguish normative tax structures from tax expenditures, though some modifications of the guideline corresponding to specific economic conditions in transition and developing economies may also are necessary. 


\section{Box 3. Identification Of The Normative Tax Structure}

Identification of the normative tax structure can best proceed by determining whether a given provision responds to one of the following questions:

1) Is the provision necessary to determine the base of the tax, normatively defined, in accordance with the fundamental nature of the tax?

2) Is the provision part of the generally applicable rate structure?

3) Is the provision necessary to define the taxable units liable for the tax?

4) Is the provision necessary to assure that the tax is determined within the time period selected for imposition of the tax?

5) Is the provision necessary to implement the tax in international transactions?

6) Is the provision necessary to administer the tax?

Source: P.R. McDaniel, and S. Surrey, “International Aspects of Tax Expenditures: A comparative Study,” Kluwer, 1984.

For example, for a typical middle income country, the guideline must be modified with additional criteria (Box 4) because this economy has a high share of population in agriculture sector (45 percent of population), a large share of employment at minimum wage and a relatively large share employed in the informal sector and unrecorded sectors (about 25 percent of GDP). That difficult economic structure, coupled with the past economic instabilities reflected in high and highly variable inflation rates, lead to specific choices of tax structures in the country. Its tax collection mostly depends on tax withholding. Therefore, additional criteria (in Box 4) have been used in identifying tax benchmarks for PIT, CIT and VAT and special customs tax.

Nevertheless, the identification of the normative tax structure is a starting point and checkpoint during the process of classification. Some provisions are on the borderline creating difficulty in determining what provisions should be included or excluded from the normative tax structures.

As a result, not all conceptual deviations from the normal tax structure should be classified as tax expenditures. To properly classify a provision as a tax expenditure or as part of the normative structure requires consideration of not only to tax theory, but also the legislative history of existing provisions, the reasons offered by proponents of a new tax proposal, and the defenses relied on rules that are proposed to be terminated or modified (P. R. McDaniel and Stanley S. Surrey, 1984). 


\section{Box 4. Additional Principal Criteria For a Tax Benchmark}

(an example for a middle income country case)

The normative tax benchmark should

- Represent a consistent tax treatment of similar activities or classes of taxpayers and neither favor nor disadvantage similarly placed activities or classes of taxpayers.

- Include certain tax provisions (such as exemptions, deductions, tax credits, and other tax preferences) to adjust taxable income in order to:

o comply with the ability-to-pay principle;

0 enhance the economic and collection efficiency of taxation;

o simplify or make feasible tax administration with respect to a class of taxpayers or type of activity.

- Ensure that tax expenditure report provides sufficient information for policy formulation.

\section{Building block 2. Estimating and projecting tax expenditures}

The estimating/accounting tax expenditures gives a quantitative measure of the size of tax expenditures and their impacts on revenue loss, direct budget expenditures, and budget balance, in addition to providing data for cost-effective analysis in tax expenditures. Projections of tax expenditures provide similar information for the medium term budget framework (MTBF).

Methods of estimating and projecting tax expenditures used include revenue foregone, revenue gain, and outlay equivalent methods. However, In the OECD and most countries' experience, the revenue foregone method is usually recommended for estimating tax expenditures.

The revenue foregone method estimates the cost of a tax expenditure as the deviation between the tax paid by taxpayers affected by a specific tax provision and tax paid by similar taxpayers not affected by that provision. The estimated value of tax expenditure is the economic value on an accrual basis and is consistent with the principal of the Government Finance Statistics (GFS) and harmonized with statistics of the 1993 System National Accounts (SNA) for revenue estimates (on accrual basis) in GFS. However, that method does not take into account changes in taxpayers' behavior.

The revenue foregone method estimates tax expenditures one at a time. It does not account for the change from the removal of one provision that may result in increased use of other provisions, lowering tax revenue elsewhere. Also, the revenue foregone method does not take into account that the removal of a tax expenditure may result in some taxpayers moving into a higher marginal tax bracket under a progressive income tax system. Those issues, however, could be tackled down with the development of technology. 
In estimating and projecting tax expenditures, a reliable database is a major factor in ensuring the reliability of the estimates. The best initial source for the database is tax returns filed by taxpayers. Other sources for the database include national accounts, population survey, industry surveys, and trade and production statistics. Those data sources are also used to cross-check tax expenditure estimates. The methods used in tax expenditure estimates and projections include the aggregate model, the distributional model, or the microsimulation model, based on the sufficiency and reliability of the database $^{16}$.

A database with sufficiently detailed data must be developed over time. It takes at least two years to develop a basic tax database for initial estimating tax expenditures. Therefore, any development relating to tax database for this purpose must be planned and begin as soon as possible.

\footnotetext{
${ }^{16}$ The detailed methodology and techniques for estimating tax expenditures could refer to related technical books.
} 


\section{Box 5: Measuring Tax Expenditures}

There are three principal ways to estimate the costs or value of tax expenditures: revenue forgone; revenue gain, outlay equivalence. All three methods are used within the OECD area.

- $\quad$ Revenue forgone. It is defined as the amount by which tax revenue is reduced because of the existence of a particular provision. It is based upon a comparison of the existing legislation and the legislation without the tax provision in question. It is an ex-post measure of the cost of a particular relief. The behavior of tax payers is taken as observed in the year for which the calculations are being made.

- Revenue gain: it is defined as the amount increased in revenue that could be expected if a particular relief were to be abolished. To obtain an accurate estimate of the revenue gain that could be expected from the withdrawal of a relief requires, in principle, that the behavioral or secondary effects associated with such a change be taken into account. These effects include: the behavioral effects of taxpayers, feedback effect and interaction between taxes (which do not take into account these secondary effects because o the difficulties involved in measuring them).

- Outlay equivalence approach. This approach estimates what direct expenditure outlays would be required, in pre-tax dollars, to achieve the same after-tax dollar benefit if a tax expenditure were replaced by a corresponding direct expenditure programmer, under which the direct outlay is accorded the tax treatment appropriate to that type of income in the hands of the recipients. This is essentially a resource cost measure.

Source: K.C. Messere, “Tax Policy in OECD Countries,” Amsterdam, 1993.

Building block 3. Integrating tax expenditures into annual budget appropriations and MTBF for fiscal accountability

Tax expenditures must be integrated into the budget to form a complete budget for fiscal accountability. As discussed previously in fiscal accountability section, integrating tax expenditures into the budget process would better coordinate tax expenditure with direct expenditures to achieve the fiscal accountability at the three levels: first, overall control within sustainable limits; second, strategic prioritization of resource allocation, and third, efficiency and cost-effective management of programs.

At first level, tax expenditures should be subject to overall controls within sustainable limits (involving medium-term expenditure frameworks), financial discipline and compliance with laws and budgets (similarly to direct budget expenditures). Tax expenditures must be analyzed along with imputed normative tax revenue, tax revenue received, direct expenditures, and fiscal deficit to form a comprehensive spending ceiling within sustainable limits.

Tax expenditures should also integrate with direct budget expenditures in order to jointly control aggregate spending and the deficit. That means tax expenditures should be 
scrutinized by similar techniques as those applied to budgetary direct expenditures. Those includes (1) setting up proper ceilings and floors to ensure tax expenditures are under control; (2) setting up a schedule for periodic re-approval/appropriation of tax expenditures to ensure financial discipline and compliance with laws and budgets; ${ }^{17}$ (3) redesign or elimination of tax expenditures deemed inefficient or outdated; (4) seeking specific savings targets in tax expenditures for the reduction of fiscal deficit. A reduction in tax expenditures could be used to meet deficit targets or facilitate the increase in other tax expenditures or direct budget expenditure programs.

To achieve savings from tax expenditures, for example, tax expenditures can be designed to use a tax credit instead of a tax deduction in a progressive tax rate structures. Because a tax expenditure interacts with tax rates, when statutory rates are higher, the ability to exclude or deduct a particular portion of one's income is worth more; consequently, tax expenditures are larger. Similarly, the value of tax expenditures like deductions or exclusions from income is greater for taxpayers in higher tax brackets than for those in lower brackets. Therefore, tax credit, tax reductions, exclusions have different effects on the cost of tax expenditures, which must be carefully considered when seeking savings in tax expenditures.

At the second level, tax expenditures should closely coordinate with direct expenditures to ensure that priorities are established that take both types of spending into account during budget appropriation. Tax expenditures could be grouped into functional classifications and each group paralleled with the corresponding functional direct budget expenditures. That enables the government to determine the total resource allocation under each of the functional areas. Also, comparison of direct expenditures with tax expenditures in the same functional area enables the government to determine whether the cost of tax expenditures is high relative to direct expenditures. In that situation, that government could consider targeting savings from tax expenditures to strategically prioritize resource allocation.

Close coordination of tax expenditures and direct expenditures during budget appropriation could ensure that overlap or duplication can be avoided. That also facilitate explicit trade-offs between tax expenditures and direct budget expenditures.

While weighing the options between eliminating tax expenditures (resulted in a tax increase) or a reducing direct budget spending on balance of budget rules, a reduction in government spending on goods and services is likely to be more harmful to the economy in the short run than an increase in taxes. The reason is that any tax increase would reduce savings rather than consumption, lessening its impact on the economy in the short run. ${ }^{18}$

\footnotetext{
${ }^{17}$ Because tax return will be filled only once a year, the periodic review may conduct once a year, once in two years, within a given schedule.

${ }^{18}$ Peter Orszag and Joseph Stiglitz, “Spending Cuts Vs. Tax Increases at the State Level: Is One More Counter-Productive Than the Other During a Recession?” Brookings Institute, Nov. 6, 2001.
} 
Many countries have tried to coordinate tax expenditures and direct expenditures while considering the priority and the effectiveness in resource allocation. Germany, for example, uses the "Subsidies Report" (which includes both budgetary subsidies and tax expenditures), which facilitate the government's decision in increase or decrease resource allocation either in tax expenditures or in direct budget expenditures.

Canadian's envelop method, for example, integrates tax expenditures into budget allocation. According to a budget spending ceiling assigned to a ministry, the ministry must decide to use either tax expenditures or direct expenditures within the assigned budget (that method was stopped due to political reasons).

At the third level, to ensure the accountability of individual tax expenditure programs, programs must be evaluated individually for relevance, effectiveness and efficiency.

Relevance concerns whether a tax expenditure is consistent with policy priorities and if it realistically address an actual need. Typically, consideration of the circumstances that led to the implementation of a tax expenditure is essential to determine if the measure continues to address a real need in a manner consistent with current social and economic conditions, as well as with policy priorities.

Relevance is also important in determining whether other policy instruments can be used to achieve the same - or similar - objectives. Alternatively, the nature of the economic or social goals and policy objectives may favor one type of instrument over another. To the extent that alternatives exist, it is necessary to ascertain whether the tax expenditure uniquely achieves some outcome that the alternatives cannot.

Effectiveness concerns whether tax expenditures are meeting objectives effectively, within budget and without unwanted outcomes. This includes the target population, changes in economic behavior or conditions, and the cost of the tax expenditures. Unintended or unforeseen effects, either positive or negative, may be important considerations in assessing effectiveness.

Efficiency concerns whether tax expenditure is the most appropriate and efficient means of achieving objectives, relative to alternative design and delivery approaches. Evaluating efficiency focus on the allocation of resources in an economy (or the level and mix of goods and services produced). When an economy is operating efficiently, resources are fully employed and producing as much output as possible.

The economic efficiency of tax expenditures can, in principle, be quantified and summarized as an overall change in real income. By influencing prices or costs, tax expenditures reallocate resources and real income among markets. They also impose compliance costs on taxpayers, as well as administration and financing costs on government. The net effect of those various influences on overall real income signals an improvement or reduction in economic efficiency and can only be determined empirically 
(Gordon, J. Lenjosek, 2004) ${ }^{19}$. Cost-effectiveness and excess burden of taxation are two main steps to evaluate economic efficiency of tax expenditures.

\section{Building block 4. Ensuring fiscal transparency in tax expenditures}

The four essential rules of the IMF's "Code of Good Practices on Fiscal Transparency" should be fully applied to tax expenditures to ensure fiscal transparency. The four rules are:

Rule 1: Clarity of roles and responsibilities

Rule 2. Public available of information

Rule 3. Budget preparation, execution, and reporting

Rule 4. Assurances of integrity

The following discusses how to ensure fiscal transparency in tax expenditures.

\section{Rule 1}

- There must be clarification of the structure and functions of the government, of the responsibilities within the government, and of the relations between governments (including central and local governments, and ministries) in authorizing and managing tax expenditures. Clear mechanisms for coordination and management of tax expenditures should be established.

- There should be a clear legal and administrative framework for the management of tax expenditures. Government spending of tax expenditures should be governed by comprehensive related laws and openly available administrative rules. Clear criteria should guide any administrative discretion in their application of tax expenditures. Ethical standards of behavior for public servants should be clear and well publicized.

\section{Rule 2}

- Comprehensive information must be publicly available on tax expenditures, including the normative/benchmark tax structures, imputed normative tax revenue, and individual tax expenditure (with rationale, sunset date, cost estimates and projections, evaluations and alternative policy options which may increase effectiveness and efficiency).

- Information must be publicly available on whether tax expenditures are considered in the preparing the annual governmental budget, specifically on whether tax expenditures are coordinated with direct expenditures in functional areas during the budgetary process and whether the use of tax expenditures has resulted in budgetary savings.

\footnotetext{
${ }^{19}$ This term is used to underscore the notion that, in general, taxes impose a burden both on the persons who must pay the tax and on society as a whole in the form of lower output.
} 
- Government should commit to the timely publication of comprehensive information of tax expenditures.

\section{Rule 3}

- A statement of fiscal policy objectives and an assessment of fiscal sustainability should include both direct budget expenditure and tax expenditures. The complete budget document should include the normative tax structures with estimates of "imputed normative tax revenue."

- Annual spending on tax expenditures should be prepared and presented within a comprehensive and consistent quantitative macroeconomic framework and the main assumptions underlying the budget should be provided.

- New tax expenditures being introduced in the annual budget should be clearly described.

- Tax expenditure information should be presented in a way that facilitates policy analysis and promotes accountability.

- Procedures for monitoring approved tax expenditures should be clearly specified.

- There should be regular fiscal reporting (annual or in a fixed time period) on tax expenditures (cost, effectiveness, and efficiency) to the legislature and the public.

\section{Rule 4}

- Tax expenditure data should reflect recent flows and trends, underlying macroeconomic developments and well-defined policy commitments.

- Tax expenditure information should be subject to independent scrutiny and the data quality should be subject to verification.

- Tax expenditures should be audited for their performance, using economy and efficiency audit and programs audit to assess the performance of the government organization, program activity or function. This audit can provide information to improve the organization's public accountability and facilitate decision making that initiates corrective action. It can also be used to assess the performance of an entity, a program or an activity within that entity to determine whether the entity has complied with significant laws and regulations of tax expenditure programs.

\section{Conclusion}

Tax incentives are tax expenditures. Tax expenditures are conceptually and functionally distinct from those tax provisions that have the purpose of raising revenue. They are government spending programs comparable to entitlement programs. Therefore, they must be analyzed in spending terms and must be integrated into the budgetary process to ensure fiscal accountability. Tax expenditures must be audited for performance, and their information must be published (with a comprehensive analysis) to achieve fiscal transparency.

The building blocks introduced in this article are useful for making tax expenditures accountable and transparent. However, they are presented in general terms. In applying the building blocks, each country must make specific decisions when it 
establishes a normative tax structure, identifies tax expenditures, and integrates tax expenditures into the budget.

For fiscal transparency, it is helpful to the public if the government publishes not only the size of tax expenditures, but also the size of the imputed normative tax revenue, which is estimated during the process of estimating tax expenditures. Thus, the public will learn not only how much government spending is in the form of tax expenditures, but also how much normative tax revenue the government would collect if there were no tax expenditures.

Furthermore, normative/benchmark tax structure, a revenue-raising component of the tax system, should be formalized. The normative/benchmark tax structure should be legally defined in the tax law and should be transparent. The tax receipts from this normative/benchmark tax structure should be quantified and published. Presently, many countries could publish imputed tax revenue from normative/benchmark tax structures, because such data is available. Only if imputed tax revenue is published in the same way as the other budget components -- tax revenue received, tax expenditures, direct expenditures and fiscal balance -- will a budget system be truly transparent in terms of revenue-raising activities and expenditure activities. In addition, when the tax revenueraising activity is formalized, the inherent spending nature of tax expenditures is further exposed. Therefore, tax expenditures should be added to direct expenditures, forming total government expenditures. In addition, the conventional concept of the size of government should be remedied by including both direct expenditures and tax expenditures.

Unfortunately, historically, in the absence of an effective program of fiscal accountability and transparency, even when some tax expenditures reduced or eliminated and tax bases are broadened during “tax reform,” new tax expenditures are often enacted soon afterwards. The total level of tax expenditures may grow back to the original level or even higher ${ }^{20}$.

Tax experts have a critical role in shaping tax expenditure policy towards fiscal accountability and transparency. To achieve this goal, tax experts should recognize the concept of tax expenditures, distinguish the inherent expenditure nature of tax expenditures from the tax revenue-raising nature of the normative/benchmark tax structures, and help the developing countries to establish building blocks of fiscal accountability and transparency to avoid repeating the unfortunate lessons of the past.

\footnotetext{
${ }^{20}$ For example, in the US, although aggregate tax expenditure revenue losses declined following implementation of the Tax Reform Act of 1986, revenue losses are growing again shortly afterward. The level of tax expenditure revenue losses fell after 1986 primarily because of rate reductions, but also because of repeal and scale-backs of may tax expenditures (GAO report 1994). According to GAO report, the aggregate tax expenditures was 402 billion USD in fiscal year 1993, it has grown to \$859 billion in fiscal year 2004. Therefore, GAO (report 2005) proposed for another tax reform in the US tax system.
} 
Finally, following the principles developed by Surrey, we hope the developing countries will benefit from the concept and scope of tax expenditures and that their fiscal systems will move towards fiscal accountability and transparency. 


\section{References}

Allan, William and Taryn Parry, "Fiscal Transparency in EU Accession Countries: Progress and Future Challenges,” IMF working paper, 2003;

Bogetic, Zeljko and Arye L Hillman "Financing Government in the Transition: Bulgaria, the Political Economy of Tax Policies, Tax Bases, and Tax Evasion,” World Bank, Washington DC, 1995.

Brixi, Hana Polackov, Christian Valenduc and Zhicheng Li Swift, "Tax ExpendituresShedding Light on Government Spending Through the Tax System,” World Bank, Washington DC, 2004.

Buchanan, James M. “Public Policy and Public Choice,” 1990.

Budget and Management Office, “Budget for Fiscal Year 2004, Historical Tables,” the United States, 2004.

Campos, José Edgardo L and Sanjay Pradhan "Building Blocks Toward A More Effective Public Sector,” World Bank Policy Research Working Paper, 1998.

Campos, José Edgardo L and Sanjay Pradhan "Evaluating Public Expenditure Management Systems: An Experimental Methodology With An Application To The Australia And New Zealand Reforms”. Journal Of Policy Analysis And Management (U.S.); 16:423-45, Summer 1997.

Campos, José Edgardo L and Sanjay Pradhan, "Budgetary Institutions And Expenditure Outcomes : Binding Governments To Fiscal Performance,” World Bank Policy Research Working Paper, 1996.

Cordes, Joseph J., Robert D. Ebel, and Jane G. Gravelle "The Encyclopedia of Taxation and Tax Policy,” The Urban Institute Press, Washington, 1999.

Craig, Jon and William Allan, "Fiscal Transparency, Tax Expenditures, and Budget Process: An International Perspective,” IMF working paper, 2001;

Department of Finance, “Tax Expenditures 2000,” Government of Canada, Ottawa, 20002004.

Congressional Budget Office, “Tax Expenditures: Budget Control Options and Five-year Budget Projections for Fiscal Year 1983-1987, the Congress of the United States, 1982.

Fiscal Affair Department, “Manual on Fiscal Transparency,” International Monetary Fund, 2001. 
Government Accountability Office, “Tax Policy, Tax Expenditures Deserve More Scrutiny” Report to the Honorable House Representatives, the Government of the United States , June, 1994.

Gupta, Anand P, “Management of tax Expenditures in India” in "Review of Management" section of "Economic and Political Weekly, Vol. XIX No 47, November 24, 1984.

Joint Committee on Taxation, "Estimates of Federal Tax Expenditures for Fiscal Years 2001-2005, U.S. Government Printing Office, 2001-2005.

Lenjosek, Gordon J. “A Framework for Evaluating Tax Measures and Some Methodological Issues” in H. P. Brixi, et al. (ed.), “Tax Expenditures -- Shedding Light on Government Spending Through the Tax System,” World Bank, Washington, 2004.

McDaniel, Paul R. and Stanley S. Surrey, (eds.), "International Aspects of Tax Expenditures: A Comparison Study,” Kluwer Law and Taxation Publishers, Deventer, the Netherlands, 1984.

Messere, Ken C., “Tax Policy in OECD Countries, Choices and Conflicts,” IBFD Publications BV, Amsterdam, the Netherlands, 1993.

OECD, “Best Practices for Budget Transparency,” Paris, 2001.

OECD, “Best Practice Guidelines_-Off Budget and Tax Expenditures,” Paris, June 2004.

Perry, David B., “Comparison of Direct Spending and Tax Expenditures,” Canadian Tax Journal, Vol. 43, No. 3, 1995.

Shende, Suresh and Tony Bennett, "Transparency and Accountability in Public Financial Administration," Concept Paper 2, "RAB/01/006: Transparency and Accountability in the Public Sector in the Arab Region,” United Nations, 2004.

Technical Report "Effectiveness and Economic Impact of Tax Incentives in the SADC Region,” (internal document), 2004.

Surrey, Stanley S. and Paul R. McDaniel, “Tax Expenditures,” Harvard University Press, Cambridge, Massachusetts, 1985.

Surrey, Stanley S. and Paul R. McDaniel, "Pathways to Tax Reform, the Concept of Tax Expenditures,” Harvard University Press, Cambridge, Massachusetts, 1973.

Treasury, “Tax expenditures Statement" Australia, 2000-2004.

World Bank, “Public Expenditure Management Handbook,” Washington, 1998. 